\title{
Use of mefloquine in children - a review of dosage, pharmacokinetics and tolerability data
}

\author{
Patricia Schlagenhauf ${ }^{*}$, Miriam Adamcova ${ }^{2}$, Loredana Regep ${ }^{2}$, Martin T Schaerer $^{2}$, Sudhir Bansod ${ }^{2}$ and \\ Hans-Georg Rhein ${ }^{2}$
}

\begin{abstract}
Background: Use of anti-malarial medication in children is hampered by a paucity of dosage, pharmacokinetic and tolerability data.
\end{abstract}

Methods: Data on the use of mefloquine in children, particularly in young children weighing less than $20 \mathrm{~kg}$, were reviewed using PubMed literature and reports on file.

Results: Chemoprophylaxis data: Two studies with a total of 170 children were found. A simulated mefloquine plasma profile showed that doses to achieve protective chemoprophylaxis blood concentration of mefloquine of approximately $620 \mathrm{ng} / \mathrm{mL}$ (or $1.67 \mu \mathrm{mol} / \mathrm{L}$ ) in children should be at least $5 \mathrm{mg} / \mathrm{kg}$. This simulated plasma profile in children corresponds to that seen in adult travellers using a weekly prophylaxis dose of $250 \mathrm{mg}$. This reinforces current practice of using weight-based dosage for children. Clearance per body weight is higher in older children. For children who travel to malaria risk areas tablets can be broken and crushed as required. It is necessary to disguise the bitter taste of the drug.

Treatment data: Mefloquine treatment (alone or in combination) data are available for more than 6000 children of all age and weight categories. The stereoselectivity and pharmacokinetic profile of mefloquine in children is similar to that observed in adults. There is higher clearance in older children (aged 5-12 years) compared to younger children (aged 6-24 months). Mefloquine treatment is well tolerated in infants (5-12 kg) but vomiting is a problem at high doses. This led to the use of a "split dose" regimen with $15 \mathrm{mg} / \mathrm{kg}$ initially, followed 12 hours later by 10 $\mathrm{mg} / \mathrm{kg}$.

Mefloquine $125 \mathrm{mg}$ has been used as intermittent preventive treatment (IPT) and was found to be efficacious in reducing episodes of malaria in a moderate-transmission setting but vomiting was a problem in $8 \%$ of children aged 2-11 months.

Mefloquine is also used as a component of artemisinin combination therapy (ACT) in small children. The combination artesunate plus mefloquine is a WHO approved first-line treatment for uncomplicated malaria in Africa.

Conclusion: Currently available data provide a scientific basis for the use of mefloquine in small children in the chemoprophylaxis setting and as a part of treatment regimens for children living in endemic areas.

\section{Background}

\section{Chemoprophylaxis}

More than 900 million international arrivals were registered in 2008 and it is estimated that $7-10 \%$ of all travellers are children. Plasmodium falciparum malaria in a young child is a life threatening disease. Early symptoms

\footnotetext{
* Correspondence: pat@ifspm.uzh.ch

'University of Zurich Centre for Travel Medicine, Hirschengraben 84, 8001

Zürich, Switzerland

Full list of author information is available at the end of the article
}

are often atypical and difficult to recognise and in nonimmune children who travel to malaria endemic areas, life-threatening complications can occur within hours of the initial symptoms [1]. Parents are advised not to travel to malaria endemic areas with small children but in reality, children comprise one in 10 of all travellers. It is essential to prevent malaria with personal protection measures and the use of an effective chemoprophylaxis in high-risk areas.

\section{Ciomed Central}


Currently, the majority of European countries, the United States of America (USA), Australia, Japan and other industrialised countries are classified as malaria non-endemic but need guidelines and effective prevention for travellers. Overall, in Europe, between 15\% and $20 \%$ of all imported malaria cases are in children. An analysis of more than 17,000 cases of imported paediatric malaria [2] showed that P. falciparum was the dominant imported species in children and that more than $75 \%$ of all paediatric cases with known place of acquisition were acquired in Africa. At highest risk are children of immigrant families visiting friends and relatives (VFR), particularly those travelling to sub-Saharan Africa, because they tend to visit high-risk destinations for prolonged periods, they lack immunity and often do not use chemoprophylaxis or preventive measures [3] and travel medicine needs to target this group of travellers [4]. The high cost of some anti-malarial medication is also a prohibitive factor for many VFR families. Malaria is thus a real threat to tourist and child expatriates visiting or living in malaria endemic areas.

All age groups of child travellers need prophylaxis including breast-fed infants, small children through to older children until young adults aged 18 years old. Mefloquine is an effective drug for malaria prevention in Africa and has the convenience of once weekly administration. There is however some uncertainty regarding the dosage of mefloquine for chemoprophylaxis in very young children and this topic is addressed here.

\section{Treatment}

There is also a need for a concise overview on data regarding mefloquine treatment in children, particularly those aged $<5$ years, who live in endemic areas and who bear the main burden of malaria. It has been estimated that $80 \%$ of malaria deaths occur in young children in Sub Saharan Africa. Mefloquine has been used recently in Africa for intermittent preventive treatment (IPTi) of malaria in infants and as a component of artemisinin combination treatment (ACT).

This review presents a summary of pharmacokinetic, dosing and tolerability data on the use of mefloquine chemoprophylaxis and treatment in children.

\section{Synthesis of evidence}

The data presented here were compiled from searches of PubMed through January 30th, 2011 using the search terms (alone or in combination) "mefloquine" and "children", "pharmacokinetics", "dosage", "safety" or "tolerability", "adverse event", "efficacy". The authors also searched their own documentation and obtained data on file from F. Hoffmann-La Roche previously submitted to Health Authorities.
A total of 445 papers in English, French or German were screened for data, particularly for data on mefloquine use in small children $(<20 \mathrm{~kg})$. Data from $41 \mathrm{stu}-$ dies were included in the tables and manuscript. The quality of the papers chosen was not assessed i.e. the selection was not restricted to randomised, double-blind studies. All studies were included that were judged to have clinically useful data on dosage, pharmacokinetics and tolerability in small children. All regimen dosages and combinations with other medication were considered. A compilation table of international guidelines on the use of mefloquine chemoprophylaxis and stand-by treatment for children visiting malaria endemic areas was also created to reflect expert opinion in the travel medicine context worldwide.

\section{Discussion of reviewed data}

\section{Pharmacokinetic basis for the dosage regimen of weekly} mefloquine chemoprophylaxis

The use of anti-malarial chemoprophylaxis in children is hampered by a lack of pharmacokinetic data and paediatric drug formulations. This is because small children are routinely excluded from many clinical studies due to the need for continuous sampling that is needed to determine drug concentration-time profiles. An intensive review of the literature and data on file (Table 1) revealed two studies on the use of mefloquine chemoprophylaxis in 170 children including young children weighing less than $20 \mathrm{~kg}$ and over 20 kg [5] (Table 1).

Some prophylaxis data on file on the use of mefloquine (in the form of the combination Fansimef ${ }^{\circledR}$ ) is valuable in the evidence synthesis. The use of mefloquine at therapy doses has been widely evaluated in infants and supports the limited available pharmacokinetic data in the chemoprophylaxis setting (Tables 2 and 3).

A first study on mefloquine in a prophylactic setting (as a component of Fansimef ${ }^{\circledR}$ ) includes a simulated plasma profile using maintenance doses of $62.5 \mathrm{mg}$ weekly mefloquine $(n=70)$ equivalent to $1 / 4$ of a tablet, the currently recommended chemoprophylactic dose in small children weighing 10-20 kg (Figure 1). This dosage leads to a blood concentration of mefloquine of approximately $620 \mathrm{ng} / \mathrm{mL}$ (or $1.67 \mu \mathrm{mol} / \mathrm{L}$ ) which is considered effective against $P$. falciparum malaria [6,7]. The plasma profile in children (Figure 1), simulated for a period of 16 weeks, corresponds to that seen for adult travellers (Figure 2) using weekly prophylaxis doses of $250 \mathrm{mg}$ mefloquine [6,7]. Weekly $62.5 \mathrm{mg}$ mefloquine or $125 \mathrm{mg}$ mefloquine every two weeks (in the form of Fansimef ${ }^{\mathbb{R}}$ ) was effective as malaria prophylaxis and well tolerated even in the children weighing $<20 \mathrm{~kg}$ (Table 1). 
Table 1 Key studies with pharmacokinetic data on mefloquine use in children and other important clinical data on prophylaxis and therapy in children

\begin{tabular}{|c|c|c|c|c|}
\hline Reference & $\begin{array}{l}\text { Children } \\
\text { Total (n) } \\
\end{array}$ & $\begin{array}{l}\text { Age } \\
\text { (in years) }\end{array}$ & $\begin{array}{l}\text { Children (n) using } \\
\text { Mefloquine }\end{array}$ & Main findings \\
\hline \multicolumn{5}{|l|}{ CHEMOPROPHYLAXIS DATA } \\
\hline $\begin{array}{l}\text { Research Report } \\
\text { Salako, Nigeria, } 1989 \\
\text { Data on file of F. Hoffmann-La Roche }\end{array}$ & 280 & $6-10 y$ & $\begin{array}{l}140 \\
\text { (with body weight range } \\
14-40 \mathrm{~kg} \text { including } 62 \\
\text { children weighing } \leq 20 \\
\mathrm{~kg} \text { ) }\end{array}$ & $\begin{array}{l}\text { Weekly } 62.5 \mathrm{mg} \text { mefloquine or } 125 \mathrm{mg} \\
\text { mefloquine every two weeks (in the form of } \\
\text { Fansimef } f^{\circledR} \text { ) was effective and well tolerated } \\
\text { even in the children weighing }<20 \mathrm{~kg} \text {. The } 62.5 \\
\text { mg weekly dose used here is equivalent to the } \\
\text { currently recommended quarter tablet for } \\
\text { malaria chemoprophylaxis in this weight } \\
\text { category }\end{array}$ \\
\hline $\begin{array}{l}\text { Weiss W. R. et al. [5] } \\
\text { Daily Primaquine Is Effective for Prophylaxis } \\
\text { against Falciparum Malaria in Kenya: } \\
\text { Comparison with Mefloquine, Doxycycline, and } \\
\text { Chloroquine plus Proguanil. } \\
\text { The Journal of Infectious Diseases, 171, 1569- }\end{array}$ & 165 & $9-14 y$ & 30 (weighing 20-54 kg) & $\begin{array}{l}\text { Kenyan school children aged 9-14 had lower } \\
\text { than expected trough levels of mefloquine after } \\
\text { standard doses ( } 5 \mathrm{mg} / \mathrm{kg} / \text { week) (mean } 406 \mathrm{ng} / \\
\mathrm{mL} \text { after } 6 \text { weeks of chemoprophylaxis). This } \\
\text { lower trough level is explained by increased } \\
\text { mefloquine clearence in older children. }\end{array}$ \\
\hline
\end{tabular}

1575, 1995

\section{TREATMENT DATA}

Luxemburger $C$ et al. [18]

Mefloquine in infants and young children.

Annals of Tropical Paediatrics 16, 281-5, 1996

\section{6}

Mefloquine treatment for uncomplicated

Falciparum malaria in young children 6-24

months of age in northern Ghana

Am J Trop Med Hyg, 76(2); 224-231, 2007

Bourahla A. et al. [10]

Stereoselective pharmacokinetics of mefloquine

in young children.

European Journal of Clinical Pharmacology 50, 241-244, 1996.

Hellgren U. et al. [24]

Standard and reduced doses of mefloquine for treatment of Plasmodium falciparum in Tanzania: whole blood concentrations in relation to adverse reactions, in vivo response, and in vitro tolerability.

Am J Trop Med Hyg 45, 254-262, 1991

Nosten F. et al. [25]

Mefloquine pharmacokinetics and resistance in

children with acute falciparum malaria.

Brit J Clin Pharmacol 31, 556-559, 1991

Singhasivanon $\mathrm{V}$, et al. [8]

Pharmacokinetics of mefloquine in children aged 6 to 24 months. European Journal of Drug Metabolism and Pharmacokinetics 17, 275-279, 1992

Singhasivanon V. et al. [9]

Pharmacokinetics of mefloquine in Thai children aged 5-12 years suffering from uncomplicated falciparum malaria treated with MSP or MSP plus primaquine.

Eur J Drug Metab Pharmacokin 19, No 1, 27-32, 1994

$>500$ and $<5 y \quad 417$

417

(with 102 children

weighing
8-12 kg with mean body weight $8 \mathrm{~kg}$ )

No serious toxicity or adverse events. High dose of mefloquine $(25 \mathrm{mg} / \mathrm{kg})$ was associated with vomiting. Mefloquine was administered to very young children aged 3-30 months. Young age was associated with a higher risk of vomiting. Split treatment dose is recommended: $15 \mathrm{mg} /$ $\mathrm{kg}$ initially, followed by $10 \mathrm{mg} / \mathrm{kg}>12$ hours later. Apart from vomiting, mefloquine was very well tolerated by young children.

Mefloquine single dose $20 \mathrm{mg} / \mathrm{kg}$ was $\begin{array}{ll}\text { (with } & \text { evaluated in Ghanaian infants. Drug levels } \\ \text { mean body weight } 8 \mathrm{~kg}) & \text { among infants that tolerated MQ well were not }\end{array}$ mean body weight $8 \mathrm{~kg}$ ) among infants that tolerated $\mathrm{MQ}$ well were
associated with age, weight or pre-existing symptoms of vomiting or diarrhea.

$12 \quad 0.5-2$ y $12 \quad$ Stereoselective pharmacokinetics in children
(with mean body weight aged 6 to 24 months are similar to those of $9.5 \mathrm{~kg}$ ) observed in adults

$53 \quad 7-10$ y $53 \quad$ The dose of $6 \mathrm{mg} / \mathrm{kg}$ and higher doses
eliminated $P$. falciparum parasites in children whereas a $2.5 \mathrm{mg} / \mathrm{kg}$ dose was not as effective. This supports the currently recommended 5 $\mathrm{mg} / \mathrm{kg}$ dosage.

$12 \quad 5-10$ y $\quad 12$

A single dose of $15 \mathrm{mg} / \mathrm{kg}$ led to whole blood $C_{\max }$ of $2031 \mathrm{ug} / \mathrm{L}, \mathrm{t}_{\max }$ mean of 8 hours (6-24) and a mean oral clearance of $0.031 \mathrm{~L} / \mathrm{h} / \mathrm{kg}$. Comparable to adults.

$12 \quad 0.5-2$ y $\quad 12$

A single dose of mefloquine $25 \mathrm{mg} / \mathrm{kg}$ led to a $C_{\max }$ of $3320 \mathrm{ug} / \mathrm{L}, \mathrm{t}_{\max } 12.8$ hours, elimination half-life (10.3 days), volume of distribution (12 L/ $\mathrm{kg}$ ) and AUC (35.6 mg/L/day) in children aged 6 months to 2 years. Comparable to adults.

$18 \quad 5-12$ y $18 \quad$ Pharmacokinetic values in older children similar
to children aged 6 months to 2 years except that clearance per body weight $(0.049 \mathrm{~L} / \mathrm{h} / \mathrm{kg})$ was higher in older children. 
Table 2 Recent Artemisinin Combination Treatment (ACT) Studies in small children

\begin{tabular}{|c|c|c|c|c|}
\hline Reference [11-16] & $\begin{array}{l}\text { Total } \\
\text { No. of } \\
\text { children }\end{array}$ & $\begin{array}{l}\text { Age } \\
\text { years/ } \\
\text { weight } \\
\text { kg }\end{array}$ & $\begin{array}{l}\text { No. of } \\
\text { children } \\
\text { treated } \\
\text { with } \\
\text { mefloquine }\end{array}$ & Important findings \\
\hline $\begin{array}{l}\text { Faye B et al. [11] } \\
\text { A randomized trial of artesunate mefloquine versus } \\
\text { artemether lumefantrine for the treatment of } \\
\text { uncomplicated Plasmodium falciparum malaria in } \\
\text { Senegalese children. } \\
\text { Am J Trop Med Hyg 82(1), 140-144, } 2010 \\
\end{array}$ & 320 & $\begin{array}{c}4-5 y \\
(10-20 \\
\mathrm{kg})\end{array}$ & 160 & $\begin{array}{l}\text { The mefloquine }(25 \mathrm{mg} / \mathrm{kg} \text { ) combination was effective } \\
>96 \% \text { and well tolerated. Even in very low weight } \\
\text { children, vomiting in mefloquine arm was less than in } \\
\text { comparator: } 30 \% \text { versus } 36 \%\end{array}$ \\
\hline $\begin{array}{l}\text { Sowunmi A et al. [12] } \\
\text { Therapeutic efficacy and effects of artesunate-mefloquine } \\
\text { and mefloquine alone on malaria-associated anemia in } \\
\text { children with uncomplicated Plasmodium falciparum } \\
\text { malaria in southwest Nigeria. } \\
\text { Am J Trop Med Hyg } 81(6), 979-986,2009\end{array}$ & 342 & $\begin{array}{l}<10 y \\
(7-46 \\
k g)\end{array}$ & 342 & $\begin{array}{l}\text { Fever and parasite clearance were faster with } \\
\text { artesunate-mefloquine }(25 \mathrm{mg} / \mathrm{kg}) \text { than with } \\
\text { mefloquine }(25 \mathrm{mg} / \mathrm{kg}) \text { alone. Resolution of anemia } \\
\text { was similar in both groups. Both regimens were } \\
\text { effective and well tolerated. }\end{array}$ \\
\hline $\begin{array}{l}\text { Tietche F et al. [13] } \\
\text { Tolerability and efficacy of a pediatric granule } \\
\text { formulation of artesunate-mefloquine in young children } \\
\text { from Cameroon with uncomplicated falciparum malaria. } \\
\text { Am J Trop Med Hyg 82(6), 1034-1040, } 2010\end{array}$ & 213 & $\begin{array}{l}\text { Mean } \\
\text { age } 3 \text { y } \\
(10-20 \\
\text { kg) }\end{array}$ & 213 & $\begin{array}{l}\text { The combination was well tolerated and highly } \\
\text { efficacious }\end{array}$ \\
\hline $\begin{array}{l}\text { Mayxay } \mathrm{M} \text { et al, [14] } \\
\text { A phase III, randomized, non-inferiority trial to assess the } \\
\text { efficacy and safety of dihydroartemisin-piperaquine } \\
\text { versus artesunate-mefloquine in patients with } \\
\text { uncomplicated Plasmodium falciparum malaria in } \\
\text { Southern Laos. } \\
\text { Am J Trop Med Hyg, 83(6)1221-1229, } 2010\end{array}$ & 205 & $<15 y$ & 69 & $\begin{array}{l}\text { Both regimens were effective, more adverse events } \\
\text { were recorded for the AM group }\end{array}$ \\
\hline $\begin{array}{l}\text { Frey SG et al. [15] } \\
\text { Artesunate-mefloquine combination therapy in acute } \\
\text { Plasmodium falciparum malaria in young children: a field } \\
\text { study regarding neurological and neuropsychiatric safety. } \\
\text { Malaria } J, 9: 291,2010\end{array}$ & 220 & $\begin{array}{c}10-20 \\
\mathrm{~kg}\end{array}$ & 220 & $\begin{array}{l}\text { Mefloquine ( } 125 \mathrm{mg} / \text { day) for } 3 \text { days (in combination } \\
\text { with artesunate }(50 \mathrm{mg} / \text { day) was well tolerated by } \\
\text { small children with a low incidence of neurological } \\
\text { and neuropsychiatric adverse events, mainly sleeping } \\
\text { disorder. All events resolved spontaneously. }\end{array}$ \\
\hline $\begin{array}{l}\text { Ramharter } \mathrm{M} \text { et al. [16] } \\
\text { Pharmacokinetics of two paediatric artesunate- } \\
\text { mefloquine drug formulations in the treatment of } \\
\text { uncomplicated falciparum malaria in Gabon. } \\
\text { J Antimicrob Chemother 60, 1091-1096, } 2007\end{array}$ & 24 & $\begin{array}{l}2-12 y \\
\text { and } \\
11-37 \\
\mathrm{~kg}\end{array}$ & 24 & $\begin{array}{l}\text { Exploratory analysis of mefloquine plasma levels } \\
\text { showed a trend towards higher concentrations in } \\
\text { younger age groups. All children, regardless of } \\
\text { formulation used, achieved therapeutic and post } \\
\text { treatment prophylactic protective levels of mefloquine }\end{array}$ \\
\hline
\end{tabular}

To date, classic pharmacokinetic studies with multiple sampling and concentration time profiles during chemoprophylaxis have not been performed in small children but this is the situation with many available malaria chemoprophylaxis medications due to the need for continuous sampling.

For children who travel to malaria risk areas tablets can be broken or cut with a blade and crushed as required. It is necessary to disguise the bitter taste of the drug using chocolate or sweet yoghurt. There are no data available on the stability of mefloquine in crushed or broken tablets and cutting of the tablets is probably best done just prior to administration.

A second study in older Kenyan school children aged 9-14 [5] showed lower than expected trough levels of mefloquine after standard doses (mean $406 \mathrm{ng} / \mathrm{mL}$ after six weeks of chemoprophylaxis), which is in agreement with the Singhasivanon studies from the early 90's $[8,9]$ that showed greater clearance of mefloquine in older children.

\section{Position of international expert groups with regard to mefloquine chemoprophylaxis}

This pivotal position of mefloquine in the prevention of malaria in small children who travel to malaria endemic areas is reflected in the international guidelines (Table 4). The major authorities, such as WHO, CDC, DTG, UK, French and Canadian expert groups recognise mefloquine as a valuable chemoprophylaxis for small children weighing $<20 \mathrm{~kg}$. For some high-risk travellers visiting friends and relatives (VFR) in their country of origin, mefloquine offers the only option for an effective, welltolerated, chemoprophylaxis for their small children who travel to high risk malaria areas in Africa. The expert groups vary in their guidelines particularly with regard to the lower weight limit for the use of mefloquine. 
Table 3 Older studies prior to year 2000 documenting mefloquine use in children

\begin{tabular}{|c|c|c|c|}
\hline $\begin{array}{l}\text { Malaria treatment studies } \\
\text { Author/Reference }\end{array}$ & $\begin{array}{l}\text { Age } \\
\text { (in years) }\end{array}$ & $\begin{array}{l}\text { No. of children treated } \\
\text { with mefloquine }\end{array}$ & $\begin{array}{l}\text { Location of the } \\
\text { study }\end{array}$ \\
\hline $\begin{array}{l}\text { Tin } \mathrm{F} \text { et al. [26] } \\
\text { Single dose treatment of falciparum malaria with mefloquine: field studies with } \\
\text { different doses in semi-immune adults and children in Burma. } \\
\text { Bull WHO 60, 913-917, } 1982\end{array}$ & $5-12$ & 89 & Myanmar \\
\hline $\begin{array}{l}\text { Chongsuphajaisiddhi T. et al. [27] } \\
\text { A phase-III clinical trial of mefloquine in children with chloroquine-resistant falciparum } \\
\text { malaria in Thailand. } \\
\text { Bull WHO } 65,223-226,1987\end{array}$ & $5-12$ & 82 & Thailand \\
\hline $\begin{array}{l}\text { Guo X.B. [28] } \\
\text { Double-blind dose finding study of mefloquine-sulfadoxine-pyrimethamine in children } \\
\text { with acute falciparum malaria. } \\
\text { Trans Roy Soc Trop Med \& Hyg 82: 538-540, } 1988\end{array}$ & $5-15$ & 60 & China \\
\hline $\begin{array}{l}\text { Sowunmi A. et al. [29] } \\
\text { Clinical efficacy of mefloquine in children suffering from chloroquine-resistant } \\
\text { Plasmodium falciparum malaria in Nigeria. } \\
\text { Transactions of the Royal Society of Tropical Medicine \& Hygiene, 84, 761-764, } 1990\end{array}$ & $0.5-11$ & 62 & Nigeria \\
\hline $\begin{array}{l}\text { Trinh T.K. [30] } \\
\text { Double-blind studies with mefloquine alone and in combination with sulfadoxine- } \\
\text { pyrimethamine in } 120 \text { adults and } 120 \text { children with falciparum malaria in Vietnam. } \\
\text { Trans Roy Soc Trop Med \& Hyg 84, No 1,50-53, } 1990\end{array}$ & $6-12$ & 80 & Vietnam \\
\hline $\begin{array}{l}\text { Slutsker L.M. et al. [31] } \\
\text { Mefloquine therapy for Plasmodium falciparum malaria in children under } 5 \text { years of } \\
\text { age in Malawi: in vivo/in vitro efficacy and correlation of drug concentration with } \\
\text { parasitological outcome. } \\
\text { Bulletin of the World Health Organization } 68,53-59,1990 .\end{array}$ & $<5$ & 121 & Malawi \\
\hline $\begin{array}{l}\text { Nosten F. et al. [32] } \\
\text { Mefloquine-resistant falciparum malaria on the Thai-Burmese border. } \\
\text { Lancet 337, 1140-1143, } 1991 .\end{array}$ & $<15$ & 245 & Thai-Myanmar border \\
\hline Sowunmi A. et al. [33] & $<5$ & 100 & Nigeria \\
\hline
\end{tabular}

Evaluation of the relative efficacy of various antimalarial drugs in Nigerian children under five years of age suffering from acute uncomplicated falciparum malaria. Annals of Tropical Medicine and Parasitology 86, 1-8, 1992.

\begin{tabular}{|c|c|c|c|}
\hline $\begin{array}{l}\text { Sowunmi A. et al. [34] } \\
\text { The relationship between the response of Plasmodium falciparum malaria to } \\
\text { mefloquine in African children and its sensitivity in vitro. } \\
\text { Trans Roy So Trop Med \& Hyg 86, 368-371, } 1992\end{array}$ & $4-12$ & 85 & Nigeria \\
\hline $\begin{array}{l}\text { Ter Kuile F. et al. [21] } \\
\text { High-dose mefloquine in the treatment of multidrug-resistant falciparum malaria. } \\
\text { Journal of Infectious Diseases 166, 1393-1400, } 1992 .\end{array}$ & $<15$ & 117 & $\begin{array}{l}\text { Thai- Myanmar } \\
\text { border }\end{array}$ \\
\hline $\begin{array}{l}\text { Ter Kuile F. et al [35] } \\
\text { Halofantrine versus mefloquine in treatment of multi-drug resistant falciparum malaria. } \\
\text { Lancet; 341:1044-1049, } 1993\end{array}$ & $<15$ & 95 & $\begin{array}{l}\text { Thai - Myanmar } \\
\text { border }\end{array}$ \\
\hline $\begin{array}{l}\text { Smithuis F.M. [36] } \\
\text { Comparison of two mefloquine regimens for treatment of Plasmodium falciparum } \\
\text { malaria on the north eastern Thai-Cambodian border. Antimicrobial agents and } \\
\text { chemotherapy, 37, No 9, 1977-1981, } 1993\end{array}$ & $<15$ & 27 & $\begin{array}{l}\text { Thai-Cambodian } \\
\text { border }\end{array}$ \\
\hline $\begin{array}{l}\text { Piarroux R. [37] } \\
\text { Choice of therapy for imported cases of falciparum malaria in children: a retrospective } \\
\text { study of } 100 \text { cases seen in Marseilles, France. } \\
\text { Trans Roy Soc Trop Med \& Hyg } 87 \text { No 1, 72-74, } 1993\end{array}$ & $<15$ & 12 & $\begin{array}{l}\text { Imported paediatric } \\
\text { malaria in France }\end{array}$ \\
\hline $\begin{array}{l}\text { Luxemburger } \text { C. et al. [38] } \\
\text { Single day mefloquine-artesunate combination in the treatment of multi-drug } \\
\text { resistant falciparum malaria. } \\
\text { Trans Roy Soc Trop Med \& Hyg, 88, 213-217, } 1994 .\end{array}$ & $<15$ & 237 & Thai-Myanmar border \\
\hline $\begin{array}{l}\text { Sowunmi A. et al. [39] } \\
\text { Open comparison of mefloquine, MSP and chloroquine in } \\
\text { acute uncomplicated falciparum malaria in children. } \\
\text { Trans Roy Soc Trop Med \& Hyg, 89, 303-305, } 1995 .\end{array}$ & $0.5-10$ & 43 & Nigeria \\
\hline
\end{tabular}


Table $\mathbf{3}$ Older studies prior to year $\mathbf{2 0 0 0}$ documenting mefloquine use in children (Continued)

\begin{tabular}{|c|c|c|c|}
\hline $\begin{array}{l}\text { Ter Kuile F. et al. [40] } \\
\text { Predictors of mefloquine treatment failure: a prospective study of } 1590 \text { patients with } \\
\text { uncomplicated falciparum malaria. Transactions of the Royal Society of Tropical } \\
\text { Medicine and Hygiene } 89,660-664,1995 .\end{array}$ & $<15$ & 752 & $\begin{array}{l}\text { Thai- Myanmar } \\
\text { border }\end{array}$ \\
\hline $\begin{array}{l}\text { Ter Kuile F. et al. [19] } \\
\text { Mefloquine treatment of acute falciparum malaria: a prospective study of non-serious } \\
\text { adverse effects in } 3673 \text { patients. } \\
\text { Bulletin World Health Organization 73, 631-642, } 1995 .\end{array}$ & $<14$ & 1319 & $\begin{array}{l}\text { Thai- Myanmar } \\
\text { border }\end{array}$ \\
\hline $\begin{array}{l}\text { Radloff PD. et al. [41] } \\
\text { Arteflene compared with mefloquine for treating Plasmodium falciparum malaria in } \\
\text { children. } \\
\text { American Journal of Tropical Medicine and Hygiene, 55, 259-262, } 1996\end{array}$ & $7-12$ & 21 & Gabon \\
\hline $\begin{array}{l}\text { Sowunmi A. et al. [42] } \\
\text { Open comparison of artemether and mefloquine in uncomplicated Plasmodium } \\
\text { falciparum hyperparasitaemia in children. } \\
\text { Annals of Tropical Paediatrics } 16,5-9,1996\end{array}$ & $1-10$ & 43 & Nigeria \\
\hline $\begin{array}{l}\text { Price RN. [43] } \\
\text { Artesunate/mefloquine treatment of multi-drug resistant falciparum malaria. } \\
\text { Trans Roy Soc Trop Med \& Hyg } 91 \text { 573-577, } 1997\end{array}$ & $<14$ & 1453 & Thai-Myanmar Border \\
\hline $\begin{array}{l}\text { Ranford-Cartwright LC. et al. [44] } \\
\text { Molecular analysis of recrudescent parasites in a Plasmodium falciparum drug efficacy } \\
\text { trial in Gabon. } \\
\text { Trans Roy Soc Trop Med \& Hyg 91, 719-724, } 1997 \\
\end{array}$ & $<15$ & 64 & Gabon \\
\hline $\begin{array}{l}\text { Okoyeh J.N. [45] } \\
\text { Responses of multidrug-resistant Plasmodium falciparum parasites to mefloquine in } \\
\text { Nigerian children. } \\
\text { Trop Med Int Health, 2, No 4, 319-324, } 1997\end{array}$ & $0.5-7$ & 33 & Nigeria \\
\hline $\begin{array}{l}\text { Lell B.et al. [46] } \\
\text { Malaria chemotherapy trial at a minimal effective dose of mefloquine-sulfadoxine- } \\
\text { pyrimethamine compared with equivalent doses of Sulfadoxine/Pyrimethamine or } \\
\text { Mefloquine alone. } \\
\text { Am J Trop Med Hyg 58, No 5, 619-624, } 1998\end{array}$ & $<15$ & 76 & Gabon \\
\hline $\begin{array}{l}\text { Luxemburger C. et al. [47] } \\
\text { Early vomiting of mefloquine in children with malaria is } \\
\text { not modified by the timing of antipyretic treatment. } \\
\text { Trans Roy Soc Trop Med \& Hyg, 92, 562-563, } 1998\end{array}$ & $2-15$ & unclear & $\begin{array}{l}\text { Thai- Myanmar } \\
\text { border }\end{array}$ \\
\hline
\end{tabular}

\section{Mefloquine treatment in children}

Data were found on mefloquine treatment in more than 6,000 children of all ages and weights (Tables 1,3) in Asia and Africa and data on the treatment of imported malaria in children in Marseille, France (Table 3). In these studies, mefloquine was used either alone or in combination with other anti-malarials. These findings indicate a predictable pharmacokinetic profile of mefloquine in children, which is similar to the pharmacokinetic profile of the drug observed in adults (i.e. mean absorption half-life of 2.1 hours, peak blood concentration after about 17 hours, slow systemic clearance, long elimination half-life - mean 18.1 days). The main age related difference in pharmacokinetics is that clearance per body weight is higher in older children aged 5-12 years compared to younger children aged 6 to 24 months $[8,9]$. A detailed pharmacokinetic study in infants with a mean weight of $9.5 \mathrm{~kg}$ showed that the stereoselectivity of mefloquine in children is similar to that observed in adults [10] which means that after administration of the racemic mixture, the pharmacokinetics at steady state are dominated by the $(-)$ enantiomer as is the case with adults.

\section{Efficacy and tolerability of mefloquine treatment in children}

Many of the early mefloquine treatment studies, prior to the year 2000 (Table 3) were conducted in children living in an area of multi-drug resistant malaria on the Thai-Myanmar border. These studies monitor the decline in the efficacy of mefloquine monotherapy in this area over time. Increasing the dose from 15 to 25 $\mathrm{mg} / \mathrm{kg}$ extended the therapeutic life of the drug in the region. Currently in multiple drug resistant areas in South East Asia, monotherapy is no longer recommended by the WHO and ACT is seen as the only option. Mefloquine $25 \mathrm{mg} / \mathrm{kg}$ combined with artesunate has been extensively evaluated in recent years [11-16] (Table 2). In Africa, many countries have moved away from mono-therapy and the WHO Malaria Treatment Guidelines 2010 ( $2^{\text {nd }}$ edition) [17] recommend the combination therapy "artesunate plus mefloquine" as a first 


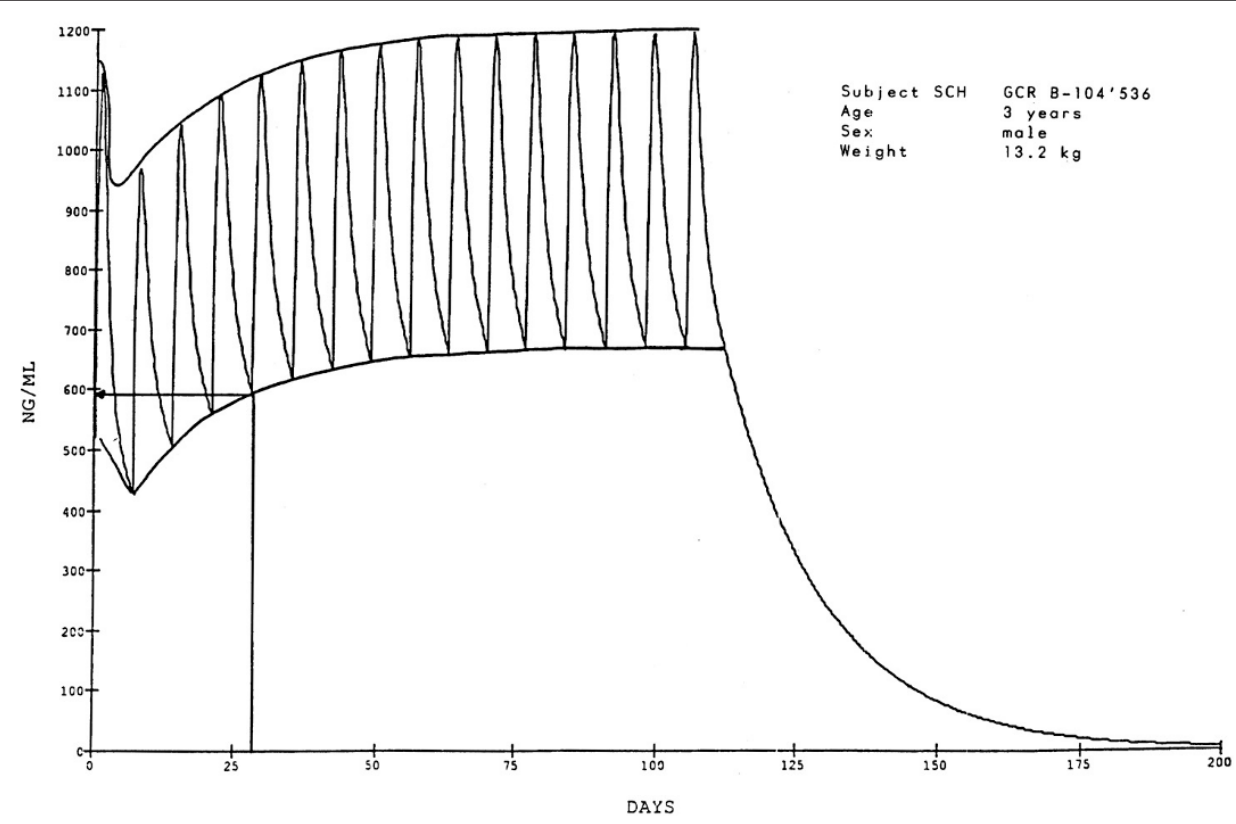

Figure 1 Plasma levels during chemoprophylaxis in children. The Figure shows the simulated plasma levels of mefloquine expected to be achieved in a child weighting $13 \mathrm{~kg}$ who received an initial dose of $125 \mathrm{mg}$ of mefloquine and then 16 weekly prophylaxis doses of $62.5 \mathrm{mg}$ mefloquine (equivalent to the currently recommended $1 / 4$ tablet for this weight category of child). Mefloquine concentrations of $\mathbf{6 2 0} \mathbf{n g} / \mathbf{m L}$ (= $1.67 \boldsymbol{\mu m o l} / \mathbf{L}$ ) are considered to be effective against Plasmodium falciparum in the bloodstream.

\section{Plasma levels (MQ, MMQ, MQ+,MQ-) during chemoprophylaxis $(250 \mathrm{mg} / \mathrm{wk})$}

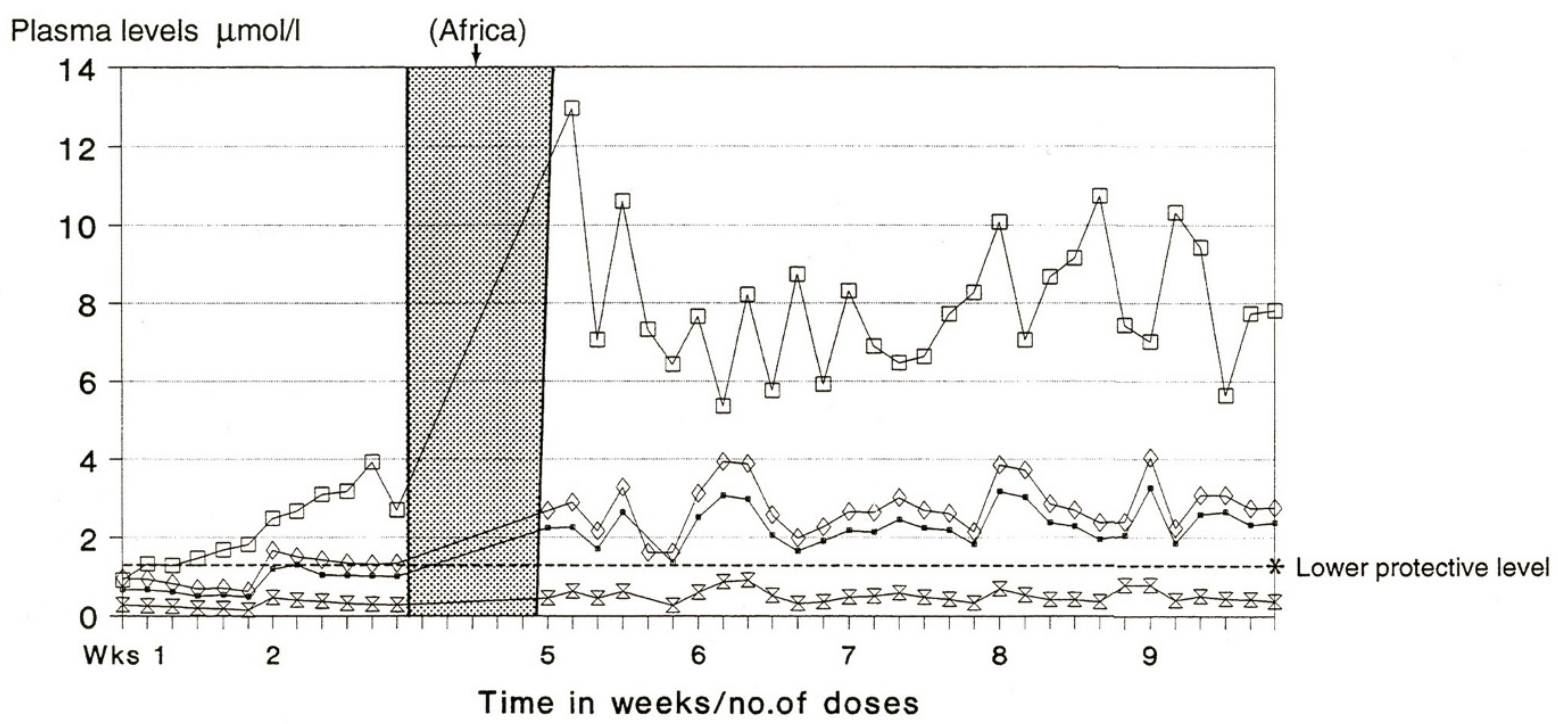

$$
\multimap \mathrm{MQ} \quad \rightarrow \mathrm{MQ}-\quad \nabla M \mathrm{M}^{+} \quad \square \mathrm{MMQ} \text {. }
$$

Figure 2 Plasma levels achieved during chemoprophylaxis in adult travellers. Data [52] showing plasma levels achieved during weekly prophylaxis in adult travellers, prior to travel in Africa and post travel. *Protective levels of mefloquine $(620 \mathrm{ng} / \mathrm{mL}$ or $1.67 \mu \mathrm{mol} / \mathrm{L})$ are achieved after two weeks of chemoprophylaxis dosing. The plasma profile in adults is similar to that in the simulated profile in children (Figure 1). MQ: mefloquine, MQ+, MQ-: mefloquine enantiomers, MMQ: carboxylic acid metabolite of mefloquine 
Table 4 International guidelines showing the importance of mefloquine (MQ) for the chemoprophylaxis of malaria

\begin{tabular}{|c|c|c|}
\hline $\begin{array}{l}\text { Authority/Expert } \\
\text { Group }\end{array}$ & MQ Chemoprophylaxis in children & $\begin{array}{l}\text { MQ Therapy of uncomplicated malaria including Stand-by } \\
\text { emergency self treatment (SBET) in children }\end{array}$ \\
\hline $\begin{array}{l}\text { WHO International } \\
\text { Travel and Health [1] }\end{array}$ & $\begin{array}{l}\text { Mefloquine recommended for chemoprophylaxis for } \\
\text { children weighting }>5 \mathrm{~kg} \text {. Dosage } 5 \mathrm{mg} / \mathrm{kg} / \text { week }\end{array}$ & $\begin{array}{l}\text { Treatment of uncomplicated malaria in children weighing }>5 \\
\mathrm{~kg} \text {. Dosage } 25 \mathrm{mg} / \mathrm{kg} \text { as split dose ( } 15 \mathrm{mg} / \mathrm{kg} \text { followed by } 10 \\
\mathrm{mg} / \mathrm{kg} 6-24 \text { hours apart) }\end{array}$ \\
\hline $\begin{array}{l}\text { DTG [48] } \\
\text { Deutsche Tropenmed. } \\
\text { Gesellschaft } \\
\text { http://www.dtg.org/ } \\
\text { uploads/media/ } \\
\text { Malaria_2010.pdf }\end{array}$ & $\begin{array}{l}\text { Mefloquine recommended for chemoprophylaxis for } \\
\text { children weighing }>5 \mathrm{~kg} \text {. Dosage } 5 \mathrm{mg} / \mathrm{kg} / \text { week }\end{array}$ & No longer routinely recommended for SBET \\
\hline \multirow[t]{6}{*}{$\begin{array}{l}\text { Canadian Guidelines } \\
\text { CATMAT[49] }\end{array}$} & $\begin{array}{l}\text { Mefloquine recommended for chemoprophylaxis in } \\
\text { travellers }>5 \mathrm{~kg} \text { body weight }(5 \mathrm{mg} / \mathrm{kg} \text { once weekly)-start } \\
3 \text { weeks before travel }\end{array}$ & Not routinely recommended for SBET \\
\hline & 5-10 kg 1/8 Tablet & \\
\hline & 10-20 kg 1⁄4 Tablet & \\
\hline & 20-30 kg 1/2 Tablet & \\
\hline & 30-35 kg 3/4 Tablet & \\
\hline & $>45 \mathrm{~kg} 1$ tablet & \\
\hline \multirow[t]{6}{*}{ CDC [50] } & Begin 1-2 weeks before travel & Not routinely recommended for SBET \\
\hline & $\leq 9 \mathrm{~kg}(5 \mathrm{mg} / \mathrm{kg}$ salt once weekly) & \\
\hline & $>9$ kg-19 kg 1/4 Tablet once weekly & \\
\hline & > 19-30 kg 1/2 Tablet once weekly & \\
\hline & $>31-45 \mathrm{~kg} 3 / 4$ Tablet once weekly & \\
\hline & $>45$ kg 1 Tablet once weekly & \\
\hline \multirow[t]{7}{*}{ UK Guidelines [51] } & Weekly mefloquine & Not routinely recommended for SBET \\
\hline & $<6 \mathrm{~kg}$ not recommended & \\
\hline & 6-9.9 kg 1/4 Tablet weekly & \\
\hline & 10-15.9 kg 1/4 Tablet weekly & \\
\hline & 16-24.9 kg 1/2 Tablet weekly & \\
\hline & 25-44.9 kg 3/4 Tablet weekly & \\
\hline & $45 \mathrm{~kg}$ and over 1 Tablet weekly & \\
\hline \multirow[t]{6}{*}{ French Guidelines [53] } & Mefloquine 5 mg/kg per week. & Not routinely recommended for SBET \\
\hline & $\begin{array}{l}\text { Start } 10 \text { days before travel, take throughout the exposure } \\
\text { period and for } 3 \text { weeks thereafter }\end{array}$ & \\
\hline & $<15 \mathrm{~kg}$ not recommended & \\
\hline & 15-19 kg: 1/4 Tablet weekly & \\
\hline & 19-30 kg: 1/2 Tablet weekly & \\
\hline & 30-45 kg: 3/4 Tablet weekly & \\
\hline
\end{tabular}

line treatment for uncomplicated malaria in Africa. The combination of a fast-acting artemisinin derivative, such as artesunate, with an anti-malarial that has sustained activity, such as mefloquine, is now an accepted approach for malaria treatment in endemic areas.

Recent studies of this ACT combination show high efficacy and good tolerability [11,12].

The early studies on mefloquine (Tables 1, 3) are however still a valuable source of information on the pharmacokinetics and tolerability of different dosages of mefloquine in children.

Luxemburger et al [18] reported on the use of mefloquine in more than 500 children under the age of 5 years including a total of 102 infants aged less than 30 months and weighing from five to $12 \mathrm{~kg}$. This study focused on efficacy and tolerability of treatment doses of mefloquine and found that vomiting was a problem at high doses $(25 \mathrm{mg} / \mathrm{kg})$ in small children which lead to the split dosage regimen $15 \mathrm{mg} / \mathrm{kg}$ initially, followed by $10 \mathrm{mg} / \mathrm{kg}>12$ hours later. Otherwise, no serious toxicity was associated with mefloquine therapy (at high doses compared to low doses recommended for chemoprophylaxis) and in particular no major neuropsychiatric abnormalities were detected. The authors concluded that mefloquine $(25 \mathrm{mg} / \mathrm{kg})$ was very well tolerated in small children weighing $>5 \mathrm{~kg}$ except for vomiting. Vomiting of malaria treatment is important due to reduced oral bioavailability and possible subsequent 
treatment failure. Mefloquine related vomiting was investigated in detail between 1990 and 1995 in Thailand [19-21]. The investigators found that $30 \%$ of children aged less than 2 years vomited after high dose mefloquine treatment $(25 \mathrm{mg} / \mathrm{kg})$ but that vomiting could be reduced by $40 \%$ when the split dose regimen $(15 \mathrm{mg} / \mathrm{kg}$ initially, followed by $10 \mathrm{mg} / \mathrm{kg}>12$ hours later) was used. It was possible to reduce mefloquineassociated vomiting by $50 \%$ by giving mefloquine on the second day in combination with artesunate. The authors concluded that high dose mefloquine was well tolerated when given as a split dose.

A more recent four-arm study of intermittent preventive treatment of malaria in infants (IPTi) in Africa compared mefloquine (125 mg), chlorproguanil (15 mg) plus dapsone (18.75 mg), sulfadoxine (250 mg) plus pyrimethamine $(12.5 \mathrm{mg})$ and placebo. Mefloquine was the most efficacious drug in reducing the incidence of clinical episodes of malaria in infants but caused vomiting in $8 \%$ of children receiving this regimen [22].

With regard to tolerability, a recent paper [15] evaluated neurological and neuropsychiatric adverse events associated with artesunate-mefloquine combination treatment in young African children. Some 220 children (weighing between 10 and $20 \mathrm{~kg}$ ) were treated with a fixed combination of artesunate $(50 \mathrm{mg} /$ day $)$ and mefloquine $(125 \mathrm{mg} /$ day $)$. The investigators used a standardized neurological assessment battery and found a low incidence of neurological and neuropsychiatric adverse events in small children $<20 \mathrm{~kg}$ who received this combination therapy. Some 50 neurological and neuropsychiatric events occurred in 28 children and 11 events in 8 patients were considered treatment related. Sleeping disorders were reported for $2.3 \%$ of children, neurological disorders in $1.4 \%$, neuropsychiatric disorders in $1 \%$ and eating disorders in $0.5 \%$ of the children. Adverse events were of mild to moderate intensity and resolved spontaneously. In an earlier study of very young Karen children in South East Asia, neither mefloquine nor artesunate resulted in significant impairment of behavior or motor function when compared with non-febrile controls [54].

\section{Conclusions}

There is an evidence base for the use of mefloquine both in paediatric chemoprophylaxis and in the treatment of paediatric malaria. The findings of the treatment studies done in children $<20 \mathrm{~kg}$ indicate a predictable pharmacokinetic profile of mefloquine in children which is similar to that observed in adults. The main age related difference in pharmacokinetics is that clearance per body weight is higher in older children aged 5-12 years compared to younger children aged 6 to 24 months. Stereoselectivity of mefloquine in children is similar to that observed in adults. Tolerability of mefloquine in small children appears superior to that in adults except for vomiting at high therapy doses, which can be mitigated by using a split dose. Two studies show a low percentage of self-limiting neurological and neuropsychiatric adverse events in children treated with artesunate/mefloquine ACT.

There are few data on chemoprophylaxis in small children but these suggest that the blood/plasma profile of mefloquine in small children is similar to that seen in adults. This dosage (for chemoprophylaxis) for children who travel to malarious areas should be at least $5 \mathrm{mg} /$ $\mathrm{kg}$ to achieve mefloquine protective levels of $620 \mathrm{ng} / \mathrm{ml}$ in the endemic region. This reasoning is followed by expert groups in travel medicine such as the WHO with the recommendations that dosage schedules should be based on weight and that mefloquine may be given to infants of more than $5 \mathrm{~kg}$ body weight. There are no data on the stability of crushed or broken tablets and cutting of the tablets is probably best done just prior to administration. The bitter taste of mefloquine chemoprophylaxis should be disguised to increase adherence.

\section{Author details \\ ${ }^{1}$ University of Zurich Centre for Travel Medicine, Hirschengraben 84, 8001 Zürich, Switzerland. ${ }^{2}$ F. Hoffmann-La Roche, 4070 Basel, Switzerland.}

\section{Authors' contributions}

PS was responsible for the concept, design, acquisition of data, analysis, interpretation of the data and writing the manuscript. MA, LR, MTS, SB, HGR contributed to data acquisition, intellectual input and critically revised the paper. All authors have seen and approved the final version.

\section{Conflict of interest statement}

This paper is based on a regulatory update done by F. Hoffmann-La Roche. PS was the external consultant who received consultancy fees for preparing the regulatory update. PS has also received research funding from Glaxo Smith Klein, F. Hoffmann-La Roche and Pfizer. PS has received speaker's honoraria from Glaxo Smith Klein, F. Hoffmann-La Roche and sigma-tau. MA, LR, MTS, SB, HGR are employees of F. Hoffmann-La Roche, Basel, Switzerland

Received: 1 March 2011 Accepted: 7 October 2011 Published: 7 October 2011

\section{References}

1. World Health Organization: International Travel and Health. WHO Geneva, Switzerland; 2011,

2. Stäger K, Legros F, Krause G, Low N, Bradley D, Desai M, Graf S, D'Amato S, Mizuno $Y$, Janzon R, Petersen E, Kester J, Steffen R, Schlagenhauf $P$ : Imported malaria in children in industrialized countries, 1992-2002. Emerg Infect Dis 2009, 15:185-191.

3. Schlagenhauf P, Adamcova M, Regep L, Schaerer MT, Rhein HG: The position of mefloquine as a 21st century malaria chemoprophylaxis. Malar J 2010, 9(9):357.

4. Hagman S, Schlagenhauf P: Imported pediatric malaria - travel medicine misses the bull's eye. J Travel Med 2011, 18:151-152.

5. Weiss WR, Oloo AJ, Johnson A, Koech D, Hoffman SL: Daily primaquine is effective for prophylaxis against falciparum malaria in Kenya: comparison with mefloquine, doxycycline, and chloroquine plus proguanil. J Infect Dis 1995, 171:1569-1575.

6. Lobel HO, Miani M, Eng T, Bernard KW, Hightower AW, Campbell CC: Longterm malaria prophylaxis with weekly mefloquine. Lancet 1993, 341:848-851. 
7. Lobel HO, Varma JK, Miani M, Green M, Todd GD, Grady K, Barber AM: Monitoring for mefloquine-resistant Plasmodium falciparum in Africa: implications for travelers' health. Am J Trop Med Hyg 1998, 59:129-132.

8. Singhasivanon V, Chongsuphajaisiddhi T, Sabcharoen A, Attanath P, Webster HK, Wernsdorfer WH, Sheth UK, Djaja Lika I: Pharmacokinetics of mefloquine in children aged 6 to 24 months. Eur J Drug Metab Pharmacokinet 1992, 17:275-279.

9. Singhasivanon V, Chongsuphajaisiddhi T, Sabchareon A, Attanath P, Webster HK, Edstein MD, Lika ID: Pharmacokinetic study of mefloquine in Thai children aged 5-12 years suffering from uncomplicated falciparum malaria treated with MSP or MSP plus primaquine. Eur J Drug Metab Pharmacokinet 1994, 19:27-32

10. Bourahla A, Martin C, Gimenez F, Singhasivanon V, Attanath P, Sabchearon A, Chongsuphajaisiddhi T, Farinotti R: Stereoselective pharmacokinetics of mefloquine in young children. Eur J Clin Pharmacol 1996, 50:241-2454

11. Faye B, Ndiaye JL, Tine R, Sylla K, Gueye A, Lô AC, Gaye O: A randomized trial of artesunate mefloquine versus artemether lumefantrine for the treatment of uncomplicated Plasmodium falciparum malaria in Senegalese children. Am J Trop Med Hyg 2010, 82:140-144

12. Sowunmi A, Gbotosho GO, Happi C, Okuboyejo T, Folarin O, Balogun S, Michael $O$ : Therapeutic efficacy and effects of artesunate-mefloquine and mefloquine alone on malaria-associated anemia in children with uncomplicated Plasmodium falciparum malaria in southwest Nigeria. Am J Trop Med Hyg 2009, 81:979-986.

13. Tietche F, Chelo D, Mina Ntoto NK, Djoukoue FM, Hatz C, Frey S, Frentzel A, Trapp S, Zielonka R, Mueller EA: Tolerability and efficacy of a pediatric granule formulation of artesunate-mefloquine in young children from Cameroon with uncomplicated falciparum malaria. Am J Trop Med Hyg 2010, 82:1034-1040.

14. Mayxay M, Keomany S, Khanthavong M, Souvannasing P, Stepniewska K, Khomthilath T, Keola S, Pongvongsa T, Phompida S, Ubben D, Valecha N, White NJ, Newton PN: A phase III, randomized, non-inferiority trial to assess the efficacy and safety of dihydroartemisinin-piperaquine in comparison with artesunate-mefloquine in patients with uncomplicated Plasmodium falciparum malaria in southern Laos. Am J Trop Med Hyg 2010, 83:1221-1229.

15. Frey SG, Chelo D, Kinkela MN, Djoukoue F, Tietche F, Hatz C, Weber P: Artesunate-mefloquine combination therapy in acute Plasmodium falciparum malaria in young children: a field study regarding neurological and neuropsychiatric safety. Malar J 2010, 9:291.

16. Ramharter M, Kurth FM, Bélard S, Bouyou-Akotet MK, Mamfoumbi MM, Agnandji ST, Missinou MA, Adegnika AA, Issifou S, Cambon N, Heidecker JL, Kombila M, Kremsner PG: Pharmacokinetics of two paediatric artesunate mefloquine drug formulations in the treatment of uncomplicated falciparum malaria in Gabon. J Antimicrob Chemother 2007, 60:1091-1096.

17. WHO: Malaria Treatment Guidelines. 2 edition. WHO, Geneva, Switzerland; 2010.

18. Luxemburger C, Price RN, Nosten F, Ter Kuile FO, Chongsuphajaisiddhi T, White NJ: Mefloquine in infants and young children. Ann Trop Paediatr $1996,16: 281-286$.

19. ter Kuile FO, Luxemburger C, Nosten F, Thwai KL, Chongsuphajaisiddhi T, White $\mathrm{NJ}$ : Predictors of mefloquine treatment failure: a prospective study of 1590 patients with uncomplicated falciparum malaria. Trans $R$ Soc Trop Med Hyg 1995, 89:660-664.

20. ter Kuile FO, Nosten F, Luxemburger C, Kyle D, Teja-Isavatharm P, Phaipun L, Price R, Chongsuphajaisiddhi T, White NJ: Mefloquine treatment of acute falciparum malaria: a prospective study of non-serious adverse effects in 3,673 patients. Bull World Health Organ 1995, 73:631-642.

21. ter Kuile FO, Nosten F, Thieren M, Luxemburger C, Edstein MD, Chongsuphajaisiddhi T, Phaipun L, Webster HK, White NJ: High-dose mefloquine in the treatment of multidrug-resistant falciparum malaria. J Infect Dis 1992, 166:1393-1400.

22. Gosling RD, Gesase S, Mosha JF, Carneiro I, Hashim R, Lemnge M, Mosha FW, Greenwood B, Chandramohan D: Protective efficacy and safety of three antimalarial regimens for intermittent preventive treatment for malaria in infants: a randomised, double-blind, placebo-controlled trial. Lancet 2009, 374:1521-1532.

23. Fryauff DJ, Owusu-Agyei S, Utz G, Baird JK, Koram KA, Binka F, Nkrumah F, Hoffman SL: Mefloquine treatment for uncomplicated falciparum malaria in young children 6-24 months of age in northern Ghana. Am J Trop Med Hyg 2007, 76:224-231.

24. Hellgren $U$, Kihamia CM, Bergqvist Y, Rombo L: Standard and reduced doses of mefloquine for treatment of Plasmodium falciparum in Tanzania: whole blood concentrations in relation to adverse reactions, in vivo response, and in vitro susceptibility. Am J Trop Med Hyg 1991, 45:254-262.

25. Nosten F, ter Kuile F, Chongsuphajaisiddhi T, Na Bangchang K, Karbwang J, White NJ: Mefloquine pharmacokinetics and resistance in children with acute falciparum malaria. Br J Clin Pharmacol 1991, 31:556-559.

26. Tin F, Hlaing N, Lasserre R: Single-dose treatment of falciparum malaria with mefloquine: field studies with different doses in semi-immune adults and children in Burma. Bull World Health Organ 1982, 60:913-917.

27. Chongsuphajaisiddhi T, Sabchareon A, Chantavanich P, Singhasivanon V, Attanath P, Wernsdorfer WH, Sheth UK: A phase-III clinical trial of mefloquine in children with chloroquine-resistant falciparum malaria in Thailand. Bull World Health Organ 1987, 65:223-226.

28. Guo XB, Arnold K, Fu LC, Chen PQ, Li GQ: Double-blind dose finding study of mefloquine-sulfadoxine-pyrimethamine in children with acute falciparum malaria. Trans R Soc Trop Med Hyg 1988, 82:538-540.

29. Sowunmi A, Salako LA, Walker O, Ogundahunsi OA: Clinical efficacy of mefloquine in children suffering from chloroquine-resistant Plasmodium falciparum malaria in Nigeria. Trans R Soc Trop Med Hyg 1990, 84:761-764.

30. Trinh KA, Nguyen VK, Arnold K, Vo VC, Nguyen NB, Kim T, Ladinsky J: Double-blind studies with mefloquine alone and in combination with sulfadoxine-pyrimethamine in 120 adults and 120 children with falciparum malaria in Vietnam. Trans R Soc Trop Med Hyg 1990, 84:50-53.

31. Slutsker LM, Khoromana CO, Payne D, Allen CR, Wirima JJ, Heymann DL, Patchen L, Steketee RW: Mefloquine therapy for Plasmodium falciparum malaria in children under 5 years of age in Malawi: in vivo/in vitro efficacy and correlation of drug concentration with parasitological outcome. Bull World Health Organ 1990, 68:53-59.

32. Nosten F, ter Kuile F, Chongsuphajaisiddhi T, Luxemburger C, Webster HK, Edstein M, Phaipun L, Thew KL, White NJ: Mefloquine-resistant falciparum malaria on the Thai-Burmese border. Lancet 1991, 337:1140-1143.

33. Sowunmi A, Salako LA: Evaluation of the relative efficacy of various antimalarial drugs in Nigerian children under five years of age suffering from acute uncomplicated falciparum malaria. Ann Trop Med Parasitol 1992, 86:1-8.

34. Sowunmi A, Oduola AM, Salako LA, Ogundahunsi OA, Laoye OJ, Walker O: The relationship between the response of Plasmodium falciparum malaria to mefloquine in African children and its sensitivity in vitro. Trans R Soc Trop Med Hyg 1992, 86:368-371.

35. ter Kuile FO, Dolan G, Nosten F, Edstein MD, Luxemburger C, Phaipun L, Chongsuphajaisiddhi T, Webster HK, White NJ: Halofantrine versus mefloquine in treatment of multidrug-resistant falciparum malaria. Lancet 1993, 341:1044-1049.

36. Smithuis FM, van Woensel JB, Nordlander E, Vantha WS, ter Kuile FO: Comparison of two mefloquine regimens for treatment of Plasmodium falciparum malaria on the northeastern Thai-Cambodian border. Antimicrob Agents Chemother 1993, 37:1977-1981

37. Piarroux R, Dumon H, Garnier JM, Lehmann M, Unal D, Quilici M: Choice of therapy for imported cases of falciparum malaria in children: a retrospective study of 100 cases seen in Marseilles, France. Trans $R$ Soc Trop Med Hyg 1993, 87:72-74.

38. Luxemburger C, ter Kuile FO, Nosten F, Dolan G, Bradol JH, Phaipun L, Chongsuphajaisiddhi T, White NJ: Single day mefloquine-artesunate combination in the treatment of multi-drug resistant falciparum malaria. Trans R Soc Trop Med Hyg 1994, 88:213-217.

39. Sowunmi A, Oduola AM: Open comparison of mefloquine, mefloquine/ sulfadoxine/pyrimethamine and chloroquine in acute uncomplicated falciparum malaria in children. Trans R Soc Trop Med Hyg 1995, 89:303-305.

40. ter Kuile FO, Luxemburger C, Nosten F, Thwai KL, Chongsuphajaisiddhi T, White NJ: Predictors of mefloquine treatment failure: a prospective study of 1590 patients with uncomplicated falciparum malaria. Trans $R$ Soc Trop Med Hyg 1995, 89:660-664.

41. Radloff PD, Philipps J, Nkeyi M, Sturchler D, Mittelholzer ML, Kremsner PG: Arteflene compared with mefloquine for treating Plasmodium falciparum malaria in children. Am J Trop Med Hyg 1996, 55:259-262. 
42. Sowunmi A, Oduola AM, llesanmi AO, Salako LA: Open comparison of artemether and mefloquine in uncomplicated Plasmodium falciparum hyperparasitaemia in children. Ann Trop Paediatr 1996, 16:5-9.

43. Price RN, Nosten F, Luxemburger C, van Vugt M, Phaipun L, Chongsuphajaisiddhi T, White NJ: Artesunate/mefloquine treatment of multi-drug resistant falciparum malaria. Trans R Soc Trop Med Hyg 1997, 91:574-577.

44. Ranford-Cartwright LC, Taylor J, Umasunthar T, Taylor LH, Babiker HA, Lell B, Schmidt-Ott JR, Lehman LG, Walliker D, Kremsner PG: Molecular analysis of recrudescent parasites in a Plasmodium falciparum drug efficacy trial in Gabon. Trans R Soc Trop Med Hyg 1997, 91:719-24.

45. Okoyeh JN, Lege-Oguntoye L, Ugbode RO, Ogunrinde GO: Responses of multidrug-resistant Plasmodium falciparum parasites to mefloquine in Nigerian children. Trop Med Int Health 1997, 2:319-24.

46. Lell B, Lehman LG, Schmidt-Ott JR, Sturchler D, Handschin J, Kremsner PG: Malaria chemotherapy trial at a minimal effective dose of mefloquine/ sulfadoxine/pyrimethamine compared with equivalent doses of sulfadoxine/pyrimethamine or mefloquine alone. Am J Trop Med Hyg 1998, 58:619-624.

47. Luxemburger $C$, van Vugt M, Slight T, Price RN, Chongsuphajaisiddhi T, Chanthavanich P, White NJ, Nosten F: Early vomiting of mefloquine in children with malaria is not modified by the timing of antipyretic treatment. Trans R Soc Trop Med Hyg 1998, 92:562-563.

48. Bialek R, Burchard GD, Jelinek T, Nothdurft HD, Schonfeld C, Volkmer K-J: Empfehlungen Malariavorbeugung. Deutsche Gesellschaft für Tropenmedizin und Internationale Gesundheit (DTG).[http://www.dtg. org].

49. Health Canada: Canadian Recommendations for the Prevention and Treatment of Malaria Among International Travellers. Canada Comm Dis Rep 2006, 30(S1):1-62[http://www.phac-aspc.gc.ca/publicat/ccdr-rmtc/ 04vol30/30s1/page3_e.html].

50. Centers for Disease Control and Prevention (CDC): Malaria. Health Information for International Travel Atlanta: US Department of Health and Human Services, Public Health Service; 2010.

51. Chiodini P, Hill D, Lalloo D, Lea G, Walker E, Whitty C, Bannister B: Guidelines for malaria prevention in travellers from the United Kingdom London, Health Protection Agency; 2007 [http://www.hpa.org.uk/infections/ topics_az/malaria/ACMP.htm]

52. Schlagenhauf $P$, Steffen R, Lobel H, Johnson R: Mefloquine tolerability during chemoprophylaxis: focus on adverse event assessments, stereochemistry and compliance. Trop Med Int Health 1996, 1:485-94.

53. Bulletin épidémiologique hebdomadaire (BEH): Recommendations sanitaires pour les voyageurs. 2010.

54. Ambler MT, Dubowitz LM, Arunjerda R, Hla EP, Thwai KL, Viladpainguen J, Singhasivanon P, Luxemburger C, Nosten F, McGready R: The neurological assessment in young children treated with artesunate monotherapy or artesunate-mefloquine combination therapy for uncomplicated Plasmodium falciparum malaria. Malaria J 2009, 8:207.

doi:10.1186/1475-2875-10-292

Cite this article as: Schlagenhauf et al:: Use of mefloquine in children - a review of dosage, pharmacokinetics and tolerability data. Malaria Journal 2011 10:292.

\section{Submit your next manuscript to BioMed Central and take full advantage of:}

- Convenient online submission

- Thorough peer review

- No space constraints or color figure charges

- Immediate publication on acceptance

- Inclusion in PubMed, CAS, Scopus and Google Scholar

- Research which is freely available for redistribution

Submit your manuscript at www.biomedcentral.com/submit
C Biomed Central 